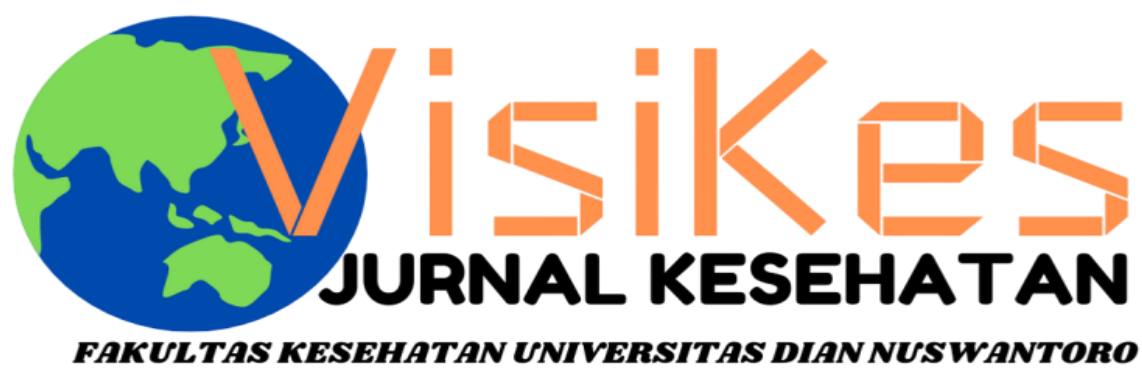

ISSN 1412-3746

FAKULTAS KESEHATAN UNIVERSITAS DIAN NUSWANTORO

Persepsi Mahasiswa Keperawatan Tentang Eskalasi Tenaga Perawat

Rendi Ariyanto Sinanto', Vivi Retno Intening ${ }^{2}$

Risiko kesehatan $\mathrm{Pb}$ dan $\mathrm{Hg}$ pada sayuran di desa Kopeng Kabupaten Semarang

Indira Casheila Anindityo ${ }^{1}$, Nur Endah Wahyuningsih ${ }^{2}$, Yusniar Hanani Darundiati ${ }^{3}$

Analisis Pelaksanaan Program Indonesia Sehat Dengan Pendekatan Keluarga (Pispk) Dalam Capaian Indeks Keluarga

Sehat Di Kabupaten Brebes Tahun 2020 Studi Pada Puskesmas Kluwut Kabupaten Brebes

Rizky Aprilianti Lestari ${ }^{1}$ dr. Antono Suryoputro ${ }^{1}$ Dr. dr. Apoina Kartini. M. Kes ${ }^{1}$

Disiplin Keselamatan dan Kesehatan Kerja melalui pemakaian alat pelindung diri di laboratorium kimia PT Sucofindo

Jakarta

Susan Endah Kartikasari ${ }^{1}$, Tatan Sukwika ${ }^{2}$

Perbedaan Pengetahuan Anemia dan Tablet Tambah Darah (TTD) Sebelum dan Sesudah Pendidikan Kesehatan Melalui

Media Video dan Aplikasi Quizlet

Devita Sari ${ }^{1}$, Gisely Vionalita ${ }^{2}$

Tingkat Pengetahuan Dan Perilaku Mahasiswi Mengenai Legalitas Dan Keamanan Kosmetik

Hani Sri Fitriani, Rizki Siti Nurfitria

Evaluasi Manajemen Dokumen Rekam Medis Di Filing Aktif Rumah Sakit Swasta Kabupaten Semarang

Bobby Anggara Laksana Putra ${ }^{1}$, Retno Astuti Setjaningsih ${ }^{2}$

Tingkat Pengetahuan Gizi Seimbang dan Profil Kesehatan Sopir Bus Antar Kota

Vilda Ana Veria Setyawati ${ }^{1}$, Bayu Yoni Setyo Nugroho ${ }^{1}$

Pengaruh Pengetahuan Dan Motivasi Kerja Terhadap Penerapan Early Warning Score System Di Rsup H Adam Malik Ita Riahna Pinem ${ }^{1}$, Zulfendri', Siti Saidah Nasution ${ }^{3}$

Analisis Penelusuran Masker Sebagai Protokol Kesehatan Saat Pandemi Covid-19 Di Indonesia: Studi Google Trends Ully Febra Kusuma ${ }^{1}$, Nurunnisa Arsyad ${ }^{2}$, Melissa Shalimar Lavinia ${ }^{3}$, Selvia Rahayu ${ }^{4}$, M. Khairul Kahfi , Rizma Adllia Syakurah ${ }^{6}$ Perilaku Hidup Bersih Dan Sehat (Phbs) Dengan Kejadian Sakit Pada Siswa Sekolah Dasar Di Kabupaten Banyumas Windri Lesmana Rubai ${ }^{1}$, Pramesthi Widya Hapsari', Katri Andirini Surijati ${ }^{3}$

Identifikasi Risiko Ganguan Muskuloskletal Pada Pekerja Percetakan Dengan Metode Nordic Body Map

Octavianus Hutapea ${ }^{1}$, Moch.Sahri', Rustam Basuki ${ }^{3}$

Literatur review: Implementasi Bauran Pemasaran 7P Terhadap Tingkat Kepuasan Pasien Di Rumah Sakit

Desi Natalia Marpaung ${ }^{1}$ Ernawaty $^{2}$ Diansanto Prayoga ${ }^{3}$ Syifa'ul Lailiyah $^{4}$

Kelengkapan Informasi Medis Untuk Mendukung Kodefikasi Penyakit Jantung Guna Mewujudkan Kualitas Data Informasi Medis Di Rumah Sakit Islam Sultan Agung Semarang

Dyah Ernawati ${ }^{1}$, Ratna Rifatul Ulya ${ }^{2}$, Arif Kurniadi ${ }^{3}$

Kajian Faktor Kendala Dokter Tidak Menggunakan Aplikasi Wifi Tb Di Kota Semarang

Arif Kurniadi', Evina Widianawati2, Dyah Ernawati ${ }^{3}$

Analisis Pelaksanaan Program Penanggulangan Tuberkulosis Paru Di Puskesmas Purwoyoso Kota Semarang

Nahari Ratu Cempaka Wilis ${ }^{1}$ Hardi Warsono ${ }^{2}$ M. Sakundarno Adi ${ }^{3}$

Hubungan Penggunaan Alat Pelindung Diri (Apd) Dengan Kadar Sgot Dan Sgpt Dalam Darah Pada Petani Padi

Iga Maliga, Rafi'ah

Faktor Risiko Kejadian Stunting Pada Balita di Wilayah Kerja Puskesmas Pandan Kabupaten Sintang

${ }^{1}$ Agustini Elisabet, ${ }^{2}$ Elvi Juliansyah

Peran Suami Dan Petugas Kesehatan Dengan Deteksi Dini Kanker Serviks

Christina Leasa, ${ }^{1}$ Mariene Wiwin Dolang

Analisis Penerapan Protokol Kesehatan terhadap Tingkat Kepatuhan Pada Pekerja informal Selama Pandemi Covid-19

MG Catur Yuantari ${ }^{1}$, Enny Rachmani ${ }^{2}$, Eti Rimawati ${ }^{1}$, Sri Handayani ${ }^{1}$, Edi Jaya Kusuma ${ }^{2}$

Peran Pengawas Minum Obat Dan Pendampingan Berobat Ulang Dengan Keberhasilan Pengobatan Tb Paru

Taswin $^{\left.1^{*}\right)}$, (zan $^{1)}$, Wahyuddin $^{1)}$, Dahmar ${ }^{1)}$

Faktor Determinan Sosial Dan Gambaran Kejadian Post Traumatic Syndrome Disorder (Ptsd) Pasca Banjir Di Dki Jakarta

Dan Bekasi Tahun 2020

Thresya Febrianti ${ }^{1}$, Nurfadhillah ${ }^{2}$, Mitha Nurhjanah ${ }^{3}$, Tiara Kautsa Aliefya ${ }^{4}$

Perbedaan Pola Makan Pada Balita Stunting Dan Tidak Stunting Di Kecamatan Teon Nila Serua (Tns) Kabupaten Maluku Tengah

Trixie Leunupun ${ }^{1}$, Ani Margawati' ${ }^{2}$ Annastasia Ediati ${ }^{3}$

Gambaran Pengelolaan Rekam Medis Rawat Inap Di Rsud Syekh Yusuf Kab. Gowa Tahun 2019

Zilfadhilah Arranury*, Surahmawati, Muhammad Rusmin, Tri Addya Karini, Dian Rezki Wijaya, Ranti Ekasari, Jihan Sulfitri

Analisis Risiko Kesehatan dalam Pemanfaatan Kemball Limbah Sludge Industri Makanan PT. X

Sri Slamet Mulyati ${ }^{1}$, Fajar Sihite ${ }^{2}$ 


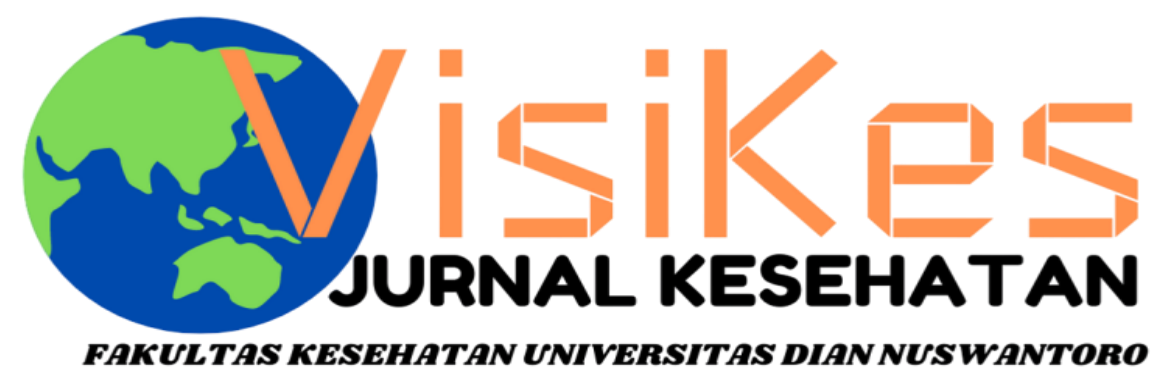

Volume 20, Nomor 1, April 2021

\section{Ketua Redaksi}

Dr. Drs. Slamet Isworo, M.Kes

\section{Penyunting}

Enny Rachmani, SKM, M.Kom, Ph.D

Fitria Wulandari, SKM, M.Kes

\section{Sekretariat}

Lice Sabata, SKM

Desain dan Layout

Puput Nur Fajri, SKM

\section{Alamat Redaksi}

Fakultas Kesehatan Universitas Dian Nuswantoro Jl. Nakula I No. 5-11 Semarang Telp/fax. (024) 3549948

email : visikes@fkes.dinus.ac.id

website $\quad$ : http://publikasi.dinus.ac.id/index.php/visikes/index

VisiKes diterbitkan mulai Maret 2002

Oleh Fakultas Kesehatan Universitas Dian Nuswantoro 


\title{
Tingkat Pengetahuan Gizi Seimbang dan Profil Kesehatan Sopir Bus Antar Kota
}

\author{
Vilda Ana Veria Setyawati ${ }^{1}$, Bayu Yoni Setyo Nugroho ${ }^{1}$ \\ ${ }^{1}$ Kesehatan Masyarakat, Universitas Dian Nuswantoro \\ E-mail: vilda.setyawati@dsn.dinus.ac.id, bayuyoni@dsn.dinus.ac.id
}

\begin{abstract}
Abstrak
Sopir mengkonsumsi makanan lebih banyak di luar rumah tanpa kontrol dari keluarganya. Apa yang mereka konsumsi sebatas untuk memenuhi rasa lapar. Tidak jarang jenis makanan yang dikonsumsi gizi hanya memberi dampak buruk bagi kesehatannya pada jangka panjang. Penelitian ini bertujuan untuk menganalisis hubungan antara pengetahuan gizi dengan profil kesehatan pada sopir

Penelitian ini merupakan penelitian kuantitatif dengan pendekatan cross sectional pada 67 sopir Bus yang diambil dengan teknik accidental sampling. Variabel bebas yang diambil adalah pengetahuan gizi, sedangkan variabel terikatnya adalah profil kesehatan yang diukur dari dua variabel, yaitu status gizi dan status hipertensi. Analisis data statistic disajikan secara deskriptif dan bivariate menggunakan software SPSS. Uji bivariate yang dipakai yaitu rank spearman.

Sebagian besar sopir yang aktif bekerja pada usia produktif $(83,6 \%)$. Sedangkan untuk jam kerja harian, 95,5\% lebih dari 8 jam per hari. Sebagian besar sopir memiliki status gizi yang normal berdasarkan indeks massa tubuh $(58,2 \%)$. Hasil yang negative ditunjukkan pada pengetahuan gizi, status gizi dan kebiasaan merokok yang sebagian besar buruk. Sopir dengan pra hipertensi $65,7 \%$, pengetahuan gizi yang kurang $82,1 \%$, dan sopir yang merokok $73,1 \%$.

Tidak ada hubungan antara pengetahuan gizi dengan status kesehatan sopir bus. Sebagian besar pengetahuan gizinya rendah, status gizinya normal, dan mengalami pra hipertensi.

Kata kunci: pengetahuan gizi, profil kesehatan, status gizi, status hipertensi
\end{abstract}

\begin{abstract}
The driver consumes more food outside the home without the control of his family. What they consume is limited to fulfilling their hunger. It is not uncommon for the type of food consumed by nutrition only to have a bad impact on health in the long term. This study aims to analyze the relationship between nutritional knowledge and the health profile of the driver

This study is a quantitative study with a cross sectional approach to 67 bus drivers who were taken using accidental sampling technique. The independent variable taken was nutritional knowledge, while the dependent variable was the health profile measured by two variables, namely nutritional status and hypertension status. Statistical data analysis presented descriptively and bivariate using SPSS software. The bivariate test used is the rank spearman.

Most of the active drivers work at productive age (83.6\%). As for the daily working hours, $95.5 \%$ is more than 8 hours per day. Most of the drivers had normal nutritional status based on body mass index (58.2\%). Negative results were shown on nutritional knowledge, nutritional status and smoking habits which were mostly poor. Drivers with pre-hypertension $65.7 \%$, poor nutritional knowledge of $82.1 \%$, and drivers who smoke $73.1 \%$.

There is no relationship between nutritional knowledge and the health status of bus drivers. Most of them have low nutritional knowledge, normal nutritional status, and have pre-hypertension.

Keyword: nutrition knowledge, health profile, nutritional status, hypertension status
\end{abstract}

\section{PENDAHULUAN}

Perkembangan dan pertumbuhan mobilitas saat ini menjadi peluang untuk bertambahkan orang yang bekerja sebagai sopir. Sebagian tenaga kerja di kota besar seperti Semarang berasal dari daerah. Ada kalanya status penduduknya hanya domisili saja tanpa mengubah status tempat tinggal asli. Bahkan ada yang tiap hari datang dan pergi ke kota hanya bekerja tanpa harus tinggal. Peluang ini dimanfaatkan sopir untuk mencari penghasilan dengan memanfaatkan 
mobilitas tersebut. Produktivitas kerja sopir yang berkualitas dilihat dari kedisiplinan dan kepuasan pelanggan. ${ }^{1}$ Para sopir selalu bekerja di jalanan dengan risiko stress dan kelelahan yang sangat tinggi. Oleh karena itu perlu dibarengi dengan hal-hal positif yang dapat meningkatkan produktivitas kerjanya. Status gizi memiliki hubungan positif dengan produktivitas pekerja. Banyak faktor lain yang berpengaruh pada hal tersebut yaitu usia, kebiasaan makan, pengaturan jam makan dan kondisi fisiologis pekerja. ${ }^{2}$

Dalam kerangka penyebab masalah gizi yang disusun oleh UNICEF, status gizi dipengaruhi secara langsung oleh konsumsi makanan dan penyakit infeksi. ${ }^{3}$ Praktek gizi seimbang mutlak dilakukan oleh semua orang, tidak terkecuali seorang sopir. Dampak yang mungkin timbul saat mereka tidak menerapkan gizi seimbang adalah asupan gizi yang berlebihan atau bahkan kurang dari kebutuhan. Survei awal yang dilakukan pada para sopir, mereka rata-rata mengkonsumsi makanan lebih banyak di luar rumah tanpa control dari keluarganya. Bahkan ada yg bekerja sebagai sopir selama 24 jam. Apa yang mereka konsumsi sebatas untuk memenuhi rasa lapar. Tidak jarang jenis makanan yang dikonsumsi gizi bisa memberi dampak buruk bagi kesehatannya. Contohnya saja saat mengkonsumsi nasi dengan lauk mie. Hal itu biasa dilakukan saat membeli makanan di warung-warung sekitar terminal. Dengan pengetahuan gizi yang cukup, diharapkan para sopir dapat menerapkan pada pola konsumsi harian sekalipun berada di luar rumah. Sopir bus memiliki kebiasaan makan yang kurang baik, meskipun demikian mereka harus tetap memiliki kondisi kesehatan yang optimal agar dapat menjalankan tugasnya.

Risiko masalah kesehatan yang didapat dari kebiasaan konsumsi makanan rendah gizi pada usia dewasa diantaranya penyakit degenerative dan kegemukan. Khususnya masalah yang timbul karena konsumsi natrium berlebih adalah hipertensi. Makin besar berat badan tubuh, semakin besar pula darah yang dibutuhkan untuk memasok oksigen ke jaringan tubuh. Hal ini berarti volume darah yang beredar melalui jaringan pembuluh darah menjadi meningkat sehingga memberi tekanan yang besar pada dinding arteri. ${ }^{4}$

Penelitian pada sopir di Manado dengan trayek antar kota menunjukkan bahwa sekitar $56 \%$ sopir mengalami hipertensi ringan dan lebih dari $40 \%$ mengalami malnutrisi bervariasi, padahal $86 \%$ memiliki pengetahuan gizi yang baik. ${ }^{5}$ Penelitian pada remaja dan dewasa aktif menunjukkan adanya hubungan antara pengetahuan gizi dan status gizi. ${ }^{6}$ Penelitian pada pekerja tahu baxo bu puji menunjukkan adanya hubungan antara status gizi dengan kelelahan. ${ }^{7}$ Berdasarkan rumusan masalah tersebut, penelitian ini bertujuan untuk menganalisis hubungan antara pengetahuan gizi dengan profil kesehatan pada sopir.

\section{METODE}

Penelitian ini merupakan penelitian kuantitatif dengan pendekatan cross sectional. Pekerja sector informal yang dimaksud adalah sopir bus dengan trayek dari Semarang ke beberapa kota di sekitarnya, seperti Demak, Solo, Surabaya. Jumlah populasi berubah 
setiap saat, sehingga teknik sampling yang digunakan accidental sampling. Pengambilan data dilakukan dalam kurun waktu 1 minggu, dimulai dari 20 November 2020 yang terkumpul sebanyak 67 orang di Banyumanik, Kota Semarang. Penelitian ini telah mendapatkan persetujuan dari komisi etik dengan nomor surat 451/KEPKFKM/UNIMUS/2020.

Variabel bebas yang diambil pengetahuan gizi yang diukur dari 8 jenis pertanyaan seputar gizi seimbang untuk dewasa. Variabel terikatnya adalah profil kesehatan yang diukur dari dua variabel, yaitu status gizi dan status hipertensi. Status gizi dihitung dari berat badan dan tinggi badan, sedangkan status hipertensi dilihat dari tekanan darah systole/diastole. Teknik pengambilan data pengetahuan gizi, berat badan, dan tinggi badan diambil dengan wawancara. Instrument penelitian yang dipakai adalah kuesioner dan tensimeter digital. Data status gizi didapat dengan menghitung indeks massa tubuh (IMT) dari data berat badan dan tinggi badan.

Kategori status gizi terdiri dari kurang gizi $\left(<18,49 \mathrm{~kg} / \mathrm{m}^{2}\right)$, normal $\left(18,5-25 \mathrm{~kg} / \mathrm{m}^{2}\right)$ dan gemuk $\left(>25,1 \mathrm{~kg} / \mathrm{m}^{2}\right) .{ }^{8}$ Kategori tensi terdiri dari normal $(<120 /<80)$, Pra-hipertensi $(120-$ 139/80 - 89), Hipertensi (>140/>90). ${ }^{4}$ Analisis data statistic disajikan secara deskriptif dan bivariate menggunakan software SPSS. Uji bivariate yang dipakai rank spearman.

\section{HASIL}

Karakteristik responden penelitian disajikan dalam bentuk deskriptif meliputi pada tabel 1 .

Tabel 1. Karakteristik pekerja sektor informal

\begin{tabular}{|c|c|c|c|c|c|c|}
\hline Variabel & Kategori & Frekuensi & Persentase & Rerata & Minimal & Maksimal \\
\hline Umur & $\begin{array}{l}\text { Tidak produktif } \\
\text { (>64 tahun) } \\
\text { Produktif } \quad(\leq 64 \\
\text { tahun) }\end{array}$ & $\begin{array}{l}1 \\
66\end{array}$ & $\begin{array}{l}1.5 \\
98.5\end{array}$ & $42,9 \pm 10,9$ & 23 & 69 \\
\hline Lama Bekerja & $\begin{array}{l}\leq 5 \text { tahun } \\
>5 \text { tahun }\end{array}$ & $\begin{array}{l}11 \\
56\end{array}$ & $\begin{array}{l}16,4 \\
83,6\end{array}$ & $17,5 \pm 10,2$ & 2 & 40 \\
\hline $\begin{array}{l}\text { Durasi jam } \\
\text { kerja }\end{array}$ & $\begin{array}{l}\text { Lebih dari jam } \\
\text { kerja (>8 jam) } \\
\text { Sesuai jam kerja }\end{array}$ & $\begin{array}{l}64 \\
3\end{array}$ & $\begin{array}{l}95.5 \\
4.5\end{array}$ & $13,8 \pm 3,5$ & 8 & 24 \\
\hline Status Gizi & $\begin{array}{l}\text { Kurang gizi } \\
\text { Normal } \\
\text { Gemuk }\end{array}$ & $\begin{array}{l}3 \\
39 \\
25\end{array}$ & $\begin{array}{l}4.5 \\
58.2 \\
37.3 \\
\end{array}$ & $24,5 \pm 3,9$ & 16,9 & 32,5 \\
\hline $\begin{array}{l}\text { Status } \\
\text { hipertensi }\end{array}$ & $\begin{array}{l}\text { Normal } \\
\text { Pra-hipertensi } \\
\text { Hipertensi }\end{array}$ & $\begin{array}{l}14 \\
44 \\
9\end{array}$ & $\begin{array}{l}20,9 \\
65,7 \\
13,4\end{array}$ & & & \\
\hline $\begin{array}{l}\text { Pengetahuan } \\
\text { Gizi }\end{array}$ & $\begin{array}{l}\text { Kurang } \\
\text { Baik }\end{array}$ & $\begin{array}{l}55 \\
12\end{array}$ & $\begin{array}{l}82.1 \\
17.9\end{array}$ & $3,36 \pm 1,3$ & 1 & 7 \\
\hline $\begin{array}{l}\text { Kebiasaan } \\
\text { merokok }\end{array}$ & $\begin{array}{l}\text { Ya } \\
\text { Tidak }\end{array}$ & $\begin{array}{l}49 \\
18\end{array}$ & $\begin{array}{l}73.1 \\
26.9\end{array}$ & & & \\
\hline
\end{tabular}

Sopir yang termuda berusia 23 tahun dan yang tertua 69 tahun. Ada 1 sopir yang sudah lansia, sisanya sopir yang aktif bekerja pada usia produktif. Sebagian besar sudah 
bekerja sebagai sopir selama lebih dari 5 tahun $(83,6 \%)$. Sedangkan untuk jam kerja harian, 95,5\% lebih dari 8 jam per hari. Sebagian besar sopir memiliki status gizi yang normal berdasarkan indeks massa tubuh $(58,2 \%)$. Hasil yang negative ditunjukkan pada pengetahuan gizi, status gizi dan kebiasaan merokok yang sebagian besar buruk. Sopir dengan pra hipertensi $65,7 \%$, pengetahuan gizi yang kurang $82,1 \%$, dan sopir yang merokok $73,1 \%$. Untuk penjelasan hasil pada masing-masing pertanyaan pengetahuan gizi ditunjukkan pada tabel 2 berikut ini:

Tabel 2. Distribusi jawaban pengetahuan gizi

\begin{tabular}{|c|c|c|c|}
\hline \multirow[t]{2}{*}{ No } & \multirow[t]{2}{*}{ Pertanyaan } & \multicolumn{2}{|l|}{ Jawaban } \\
\hline & & Benar & Salah \\
\hline 1 & Makanan beragam terdiri dari & $22(32,8 \%)$ & $45(67,2 \%)$ \\
\hline 2 & $\begin{array}{l}\text { Berapa kali dalam sehari harus mengkonsumsi sayur } \\
\text { dan buah }\end{array}$ & $5(7,5 \%)$ & $62(92,5 \%)$ \\
\hline 3 & $\begin{array}{l}\text { Apakah mengkonsumsi sayur } 3 \text { kali sehari sudah } \\
\text { cukup memenuhi kebutuhan gizi apabila sayurannya } \\
\text { hanya banyak kuah dengan sedikit ampas }\end{array}$ & $24(35,8 \%)$ & $43(64,2 \%)$ \\
\hline 4 & Manfaat sarapan untuk pekerjaan mengemudi.... & $45(67,2 \%)$ & $22(32,8 \%)$ \\
\hline 5 & $\begin{array}{l}\text { Konsumsi mie dan nasi secara bersamaan } \\
\text { merupakan masalah karena... }\end{array}$ & $7(10,4 \%)$ & $60(89,6 \%)$ \\
\hline 6 & $\begin{array}{l}\text { Sumber lemak dan protein terbaik untuk usia dewasa } \\
\text { yaitu }\end{array}$ & $36(53,7 \%)$ & $31(46,3 \%)$ \\
\hline 7 & $\begin{array}{l}\text { Saya berusia dewasa harus memenuhi kebutuhan } \\
\text { gizi seimbang agar... }\end{array}$ & $51(76,1 \%)$ & $16(23,9 \%)$ \\
\hline 8 & Konsumsi cairan perhari minimal ... gelas / hari & $35(52,2 \%)$ & $32(47,8 \%)$ \\
\hline
\end{tabular}

Distribusi kemampuan menjawab nomor 4, 6, 7, dan 8. Sedangkan untuk pertanyaan antara yang salah dan benar menunjukkan persentase yang seimbang. jawaban yang salah yaitu pada pertanyaan Jawaban yang benar sebagian besar pada nomor 1, 2, 3, dan 5 .

Table 3. Tabulasi silang antara pengetahuan gizi dengan status gizi

\begin{tabular}{|c|c|c|c|c|c|}
\hline & & $\begin{array}{l}\text { Status Gizi } \\
\text { Kurang Gizi }\end{array}$ & Normal & Gemuk & Total \\
\hline $\begin{array}{l}\text { Penget } \\
\text { ahuan } \\
\text { gizi } \\
\text { Total }\end{array}$ & $\begin{array}{l}\text { Kurang } \\
\text { Baik }\end{array}$ & $\begin{array}{l}3 \\
5.5 \% \\
0 \\
0.0 \% \\
3 \\
4.5 \%\end{array}$ & $\begin{array}{l}31 \\
56.4 \% \\
8 \\
66.7 \% \\
39 \\
58.2 \%\end{array}$ & $\begin{array}{l}21 \\
38.2 \% \\
4 \\
33.3 \% \\
25 \\
37.3 \%\end{array}$ & $\begin{array}{l}55 \\
100 \% \\
12 \\
100 \% \\
67 \\
100 \%\end{array}$ \\
\hline
\end{tabular}

Berdasarkan tabel di atas, tidak ada hubungan antara pengetahuan gizi dengan status gizi $(p>0,05)$. Berdasarkan hasil tabulasi silang, sopir dengan pengetahuan gizi baik dan kurang, sebagian besar memiliki status gizi yang normal. Sopir dengan pengetahuan gizi baik dan berstatus gizi normal sebesar $56,4 \%$, sedangkan yang berpengetahuan baik dan 
status gizi normal sebesar $66,7 \%$. Meskipun demikian ada hubungan positif jika membandingkan persentase sopir yang berpengetahuan gizi baik dan kurang pada sel status gizi normal.

Tabel 4. Tabulasi silang Pengetahuan gizi dengan status hipertensi

\begin{tabular}{|c|c|c|c|c|c|}
\hline & & normal & $\begin{array}{c}\text { Status Hipertens } \\
\text { pra-hipertensi }\end{array}$ & hipertensi & Total \\
\hline $\begin{array}{l}\text { Pengetahuan } \\
\text { gizi }\end{array}$ & $\begin{array}{l}\text { Kurang } \\
\text { Baik }\end{array}$ & $\begin{array}{l}10 \\
18.2 \% \\
4 \\
33.3 \%\end{array}$ & $\begin{array}{l}37 \\
67.3 \% \\
7 \\
58.3 \%\end{array}$ & $\begin{array}{l}8 \\
14.5 \% \\
1 \\
8.3 \%\end{array}$ & $\begin{array}{l}55 \\
100 \% \\
12 \\
100 \%\end{array}$ \\
\hline \multicolumn{2}{|c|}{ Total } & $\begin{array}{l}14 \\
20.9 \%\end{array}$ & $\begin{array}{l}44 \\
65.7 \%\end{array}$ & $\begin{array}{l}9 \\
13.4 \%\end{array}$ & $\begin{array}{l}67 \\
100 \%\end{array}$ \\
\hline
\end{tabular}

$\mathrm{p}=0,3$ (rank spearman test)

Berdasarkan tabel di atas, tidak ada hubungan antara pengetahuan gizi dengan status hipertensi. Tabulasi silang menunjukkan, sopir dengan pengetahuan baik atau kurang, sebagian besar mengalami pra hipertensi. Sopir dengan pengetahuan baik dan menderita pra hipertensi sebesar $67,3 \%$, sedangkan yang berpengetahuan kurang dan menderita hipertensi sebesar 58,3\%. Meskipun demikian, hubungan pengetahuan gizi dan status hipertensi pada penelitian ini sesuai dengan teori dimana semakin tinggi pengetahuan gizi, semakin tinggi pula tingkat preferensi untuk makanan yang bergizi.

\section{PEMBAHASAN}

Sebagian besar sopir berusia produktif antara 25-64 tahun (tabel 1). Sebagai syarat awal untuk bekerja sebagai sopir, umurnya pada penelitian ini sudah memenuhi. Umur yang masih produktif berkontribusi pada konsentrasi, daya tahan dan kemampuan mengendalikan mesin. Akan tetapi seiring memasuki usia lansia, kemampuan tersebut akan berkurang yang tentunya membahayakan dirinya sendiri dan para penumpang. ${ }^{9}$ Pekerjaan sopir yang membawa bus antar kota membuat mereka kadang tidak memiliki pilihan untuk bekerja lebih dari jam kerja yang ditentukan oleh kementerian yaitu selama 7 jam untuk 6 hari kerja, dan 8 jam untuk 5 hari kerja. ${ }^{10}$ Bahkan sopir pada penelitian ini ada yang bekerja 24 jam penuh (tabel 1). Meskipun demikian, saat berada pada situasi ini, setelah itu akan diambil libur untuk tidak menyetir. Kondisi seperti ini berisiko memberi dampak buruk pada kesehatan ke depannya mengingat setidaknya manusia diwajibkan memenuhi jam tidur selama 6-8 jam per hari. Para sopir juga memiliki pengalaman yang cukup sebagai seorang sopir dilihat dari sebagian besar yang sudah bekerja selama lebih dari 5 tahun. Bahkan ada yang sudah bertahan selama 40 tahun (tabel 1). Posisi duduk dalam waktu lama berpengaruh pada masalah muskoloskeletal. Saat mengemudi sopir membutuhkan waktu yang lama dan mendorong ke arah ketidaknyamanan dan timbul penyakit yang berakibat kerugian besar dan berimbas pada pengurangan produktivitas kerja. ${ }^{11}$ 
Konsep kesehatan kerja berkembang bukan hanya pada sector industry saja tetapi juga mengarah pada upaya kesehatan untuk semua orang dalam melakukan pekerjaan. Penyelenggaraan upaya kesehatan kerja (UKK) merupakan strategi pengembangan kesehatan kerja sektor informal yang meliputi pelayanan promotif, preventif, kuratif, dan rehabilitatif. Para sopir harus menerapkan perilaku kesehatan selama bekerja agar terhindar dari masalah kesehatan. Akan tetapi, perkembangan informasi kesehatan dan kondisi kesehatan pekerja sector informal kurang mendapat perhatian sehingga perlu dilakukan upaya pemerataan kesehatan bagi para pekerja untuk mewujudkan pekerja yang sehat, mandiri, dan berkeadilan. ${ }^{12}$ Oleh karena itu penting bagi seorang sopir untuk meningkatkan pengetahuan gizinya.

Pengetahuan gizi merupakan kemampuan setiap orang untuk memiliki pengetahuan dan keterampilan dalam proses memahami informasi gizi dan sebagai alat untuk mengubah perilaku. ${ }^{13}$ Sebanyak $82,1 \%$ sopir memiliki pengetahuan gizi yang kurang. Secara statistik tidak ada hubungan antara pengetahuan gizi dengan status gizi dan hipertensi (tabel 3 dan 4). Hasil ini sejalan dengan penelitian di Palembang bahwa tidak ada hubungan antara tingkat pengetahuan gizi dengan tekanan darah sistolik dan diastolic pada orang dewasa. ${ }^{14}$ Pengetahuan yang cukup menjadi salah satu dasar bahwa responden memiliki status kesehatan yang baik jika tidak diimbangi dengan perubahan perilaku. Tidak adanya hubungan antara pengetahuan gizi dengan status gizi juga didukung hasil penelitian pada pegawai di rumah sakit di Jakarta. Perubahan perilaku akan melalui proses, yaitu perubahan pengetahuan, sikap, kemudian praktik. Beberapa penelitian membutkikan bahwa pengetahuan yang baik akan merubah sikap dan pada akhirnya mengubah praktek kesehatan. Belum tentu orang yang memiliki pengetahuan kesehatan atau gizi yang tinggi sudah pasti mempraktekkan apa yang dipahaminya. Bahnyak faktor lain yang berpengaruh untuk mewujudkan perilaku gizi yang positif. ${ }^{15}$

\section{KESIMPULAN}

Sebagian besar sopir yang aktif bekerja pada usia produktif $(83,6 \%)$. Sedangkan untuk jam kerja harian, 95,5\% lebih dari 8 jam per hari. Sebagian besar sopir memiliki status gizi yang normal berdasarkan indeks massa tubuh $(58,2 \%)$. Hasil yang negative ditunjukkan pada pengetahuan gizi, status gizi dan kebiasaan merokok yang sebagian besar buruk. Sopir dengan pra hipertensi $65,7 \%$, pengetahuan gizi yang kurang $82,1 \%$, dan sopir yang merokok $73,1 \%$. Tidak ada hubungan antara pengetahuan gizi dengan status kesehatan sopir bus. Sebagian besar pengetahuan gizinya rendah, status gizinya normal, dan mengalami pra hipertensi.

\section{DAFTAR PUSTAKA}

1. Halim IA. Pengaruh Kepuasan Kerja Dan Disiplin Kerja Pada Kualitas Layanan Sopir Di Pt Usaha Jaya Gresik. Agora. 2015;3(2).

2. Ramadhanti AA. Status Gizi dan Kelelahan terhadap Produktivitas Kerja. J IIm Kesehat Sandi Husada. 
2020;11(1):213-8.

3. Setyawati. dasar ilmu Gizi Kesehatan Masyarakat Indonesia [Internet]. 1st ed. Deepublish. Semarang: Dee Publishing; 2019. 167 p. Available from: https://books.google.co.id/books?id=YAC DDwAAQBAJ\&printsec $=$ frontcover\&dq $=\mathrm{il}$ mu+gizi\&hl=id\&sa=X\&ved=0ahUKEwihnJ HGp_7oAhXyjeYKHds4B84Q6AEIKDAA\# $\mathrm{v}=$ onepage $\& \mathrm{q}=\mathrm{ilmu}$ gizi\&f=false

4. Schwartz GL, Sheps SG. A review of the Sixth Report of the Joint National Committee on Prevention, Detection, Evaluation, and Treatment of High Blood Pressure. Curr Opin Cardiol. 1999;14(2):161-8.

5. Ramdan IM. Memperbaiki Kondisi Kesehatan Dan Keselamatan Kerja Sektor Informal Melalui Program Corporate Social Responsibility Perusahaan. J Heal Care Manajement [Internet]. 2012;15(1):3. Available from: https://journal.ugm.ac.id/jmpk/article/dow nload/2505/2241.

6. Robert D, Harikedua VT, Tulung SC. Pengetahuan Stiker 10 Pesan Gizi Seimbang Terhadap Status Gizi Dan Hipertensi Pada Sopir Minibus Jurusan Manado-Gorontalo Di Rest Area Desa Busisingo. 2016;8(1):92-101.

7. Langgar D., Setyawati VA V. Hubungan Antara Asupan Gizi dan Status Gizi dengan Kelelahan Kerja Pada Karyawan Perusahaan Tahu Baxo Bu Pudji di Ungaran Tahun 2014. J Kesehat. 2014;7(2):353-60.

8. Thamaria N. Penilaian Status Gizi.
Jakarta: Kementerian Kesehatan RI; 2017. 200-236 p.

9. Analisis Perilaku Keselamatan Mengemudi (Safety Driving) Pada Sopir Bus PO X Slawi Tegal. Vol. 10, Media Kesehatan Masyarakat Indonesia Universitas Diponegoro. 2011. p. 81-7.

10. Undang-Undang Republik Indonesia No. 13 Tahun 2003. Undang-Undang Republik Indonesia No.13 Tahun 2003 tentang Ketenagakerjaan. Undang-Undang [Internet]. 2003;(1):1-34. Available from: http://www.kemenperin.go.id/kompetensi/ UU_13_2003.pdf

11. Markos Klonizakis, Garry A tew, Jonathan A. Michaels JMS. Effects Of Upper Limb Exercise On Lower Limb Cutaneous Microvascular Function In Post Surgical Varicose Vein Patients. Eur J Appl Physiol. 2010;109(10 April):1221-4.

12. Yusida H, Suwandi T, Yusuf $A$, Sholihah Q. Kepedulian Aktif untuk K3 Sektor Informal. PT Graf Wangi Kalimantan. 2017;1-29.

13. Michou M, B Panagiotakos D, Lionis C, Petelos E, Costarelli V. Health and nutrition literacy levels in Greek adults with chronic disease. Public Heal Panor. 2019;5(2-3):271-9.

14. Susyani, Hartati Y, Afriani L. Hubungan pengetahuan gizi,pola makan dan tingkat kepatuhan diet dengan tekanan darah pasien hipertensi rawat jalan di Rumah Sakit Mohammad Hoesin palembang. Pembang Mns [Internet]. 2014;8:94-103. Available from: google cendekia

15. Agustin F, Fayasari A, Dewi GK. 
Pengetahuan, sikap, dan perilaku gizi seimbang terhadap status gizi lebih pada pegawai Rumah Sakit Penyakit Infeksi
Sulianti Saroso Jakarta Utara. IImu Gizi Indones. 2018;1(2):93. 